Author version: Estuar. Coast. Shelf Sci., vol.95; 2011; 359-366

\title{
Phylogenetic diversity of carbohydrate degrading culturable bacteria from Mandovi and Zuari estuaries, Goa, west coast of India
}

\author{
Rakhee Khandeparker ${ }^{* 1}$, Preeti Verma ${ }^{1}$, Ram M. Meena ${ }^{1}$, Deepti D. Deobagkar² \\ ${ }^{1}$ National Institute of Oceanography, CSIR, Goa- 403 004, India \\ ${ }^{2}$ Molecular Biology Research Laboratory, Centre of Advanced Studies, \\ Department of Zoology, University of Pune, 411007, India
}

\footnotetext{
${ }^{*}$ Corresponding author:

E-mail: rakhee@nio.org (Rakhee Khandeparker)

Tel.: +91 832 2450540; fax: +91 8322450606
}

\begin{abstract}
Coastal and estuarine waters are highly productive and dynamic ecosystems. The complex carbohydrate composition of the ecosystem would lead to colonisation of microbial communities with abilities to produce an array of complex carbohydrate degrading enzymes. We have examined the abundance and phylogenetic diversity of culturable bacteria with abilities to produce complex carbohydrate degrading enzymes in the Mondovi and Zuari eustauri. It was interesting to note that $65 \%$ of isolated bacteria could produce complex carbohydrate degrading enzymes. A majority of these bacteria belonged to Bacillus genera followed by Vibrio, Marinobacter, Exiquinobacterium, Alteromonas, Enterobacter and Aeromonas. Most abundant bacterial genus to degrade hemicellulose and cellulose were Bacillus and Vibrio respectively. Most abundant bacterial genus to degrade hemicellulose and cellulose were Bacillus and Vibrio respectively. It was seen that $46 \%$ of Bacillus had ability to degrade both the substrate while only $14 \%$ of Vibrio had bifunctionality.
\end{abstract}

Keywords: Hemicellulose, Cellulose, Bacteria, Carbohydrates, Phylogeny 


\section{Introduction}

The rich estuarine ecosystem offers an example of dynamics of river with contribution from activities along the coast. Total soluble carbon is an important measure of richness and bioactivity of this ecosystem. However understanding the metabolic fluxes would require not only the composition of organic and inorganic components but also the contribution of microbes to these cycles. In aquatic systems the dissolved carbohydrates, especially the polymeric substrates, are the most abundant molecules in nature and are used by most organisms as structural and/or storage compounds. Among the carbohydrates the most abundant are cellulose, starch and xylans, which also represent the largest renewable source of energy known (Rosado and Govind, 2003).

Studies of lignocellulose degradation under saline conditions are important in terms of understanding carbon flux within marine environments. (Pointing and Hyde, 2000). Carbohydrates are one of the major forms of organic substrates in the aquatic environment contributing up to $80 \%$ of the dissolved and 5-25\% of the particulate organic carbon (Decho, 1990, Benner et al. 1992, Biersmith and Benner, 1998). Bacteria play an important role in the regulation of rate of organic matter mineralization, nutrient cycling, and energy transfer in aquatic environments (Lennon 2007, Azam and Warden, 2004). The remineralization and the turnover of carbohydrates has been used to evaluate the efficiency of the microbial community and the lability of the organic carbon in coastal waters. The ocean environment is complex, consisting of extreme variations in pressure, salinity, temperature, and biological habitats. The biota of marine microorganisms has developed unique metabolic and physiological functions that not only ensure survival in extreme habitats but also offer a potential for the production of novel enzymes and bioactive metabolites for potential exploitation (Ninawe and kuhad, 2006, Beleneva et al., 2010).

Carbohydrases are enzymes that break down carbohydrates into simple sugars. They are important in life processes and find a number of industrial applications. Acting in a singular or synergistic manner they permit the use of low value biomass for the industrial production of paper, textiles, chemicals, feed stuff, bio-fuels and offer alternatives for currently used toxic substances (Gilbert and Hazlewood, 1991 Rosado and Govind, 2003, Maki et al. 2009).

In view of the important role played by microbes in recycling of carbon and bioremediation, we have isolated marine bacteria which are producers of carbohydrate degrading enzymes and characterised their phylogenetic diversity.

\section{Materials and Methods}

\subsection{Study area}

The coastal region selected for our study was the Mandovi-Zuari riverine area. The Mandovi river originates from the Western Ghats (mountain pass) of the Indian peninsula and flows from east to west over a length of $\mathrm{N} 75 \mathrm{~km}$ through the rocky terrain of Goa, draining into the Arabian Sea, along the west coast of India. Fig. 1 shows the sampling area in the Mandovi river estuarine system. The 
estuarine banks of Mandovi and Zuari have mangroves, which harbour sediments rich in organic matter. They support several flora and fauna that are either resident or migratory and act as nursery grounds and nutrient sources for a variety of economically and ecologically important organisms, including fishes, prawns and many other invertebrates. Also these estuaries are used for transport of iron and manganese ores.

Fig.1. Mandovi and Zuari estuary.

\subsection{Sample collection and isolation of bacterial cultures}

Soil and water samples (2 samples per site) were collected in sterile $50 \mathrm{ml}$ polypropylene tubes. These were immediately transported to the laboratory. $1 \%$ soil suspension with sterile distilled water or sterile sea water was prepared and $0.1 \mathrm{ml}$ of the sample suspension was plated out on solid rich nutrient medium Luria-Bertani Agar or Zobell Marine Agar. Water samples were plated out with different dilutions on the plates. Individual colonies were isolated from these plates and streaked separately on Zobell marine agar plates to get isolated pure colonies. From here they were transferred on Zobell marine agar slants and preserved at $4^{\circ} \mathrm{C}$.

\subsection{Screening marine bacteria for production of cellulases, hemicellulases, and amylases}

To screen the isolates degrading hemicellulose all the isolates were spotted on xylan-agar plates (Zobell marine agar/ Luria agar containing 1\% xylan) and incubated at room temperature for $24 \mathrm{~h}$ and the zone of clearence was observed by flooding the plate with $1 \%$ Congo-red and then washing the agar with $1.5 \mathrm{M} \mathrm{NaCl}$ (Sa-Pereira et al. 2002). Similarly for the bacteria degrading cellulose all the isolates were spotted on CMC-agar plates (Zobell marine agar/ Luria-Bertini agar containing 1\% carboxymethyl cellulose), and the zone of clearance was observed as described above for xylan plates. The amylase producers were isolated on starch agar plates.

\subsection{Bacterial DNA extraction}

Bacterial genomic DNA was isolated using a modification of existing techniques (Ausubel et al. 1995). Briefly the technique entailed the following: $5 \mathrm{ml}$ of mid- to late log phase bacteria were collected by centrifugation and resuspended in a small volume of lysis buffer $(0.05 \mathrm{M}$ Tris $\mathrm{HCL} \mathrm{pH}$ 8.0, 0.01M EDTA). SDS was added to this solution at a final concentration of $0.5 \%$, mixed gently and incubated for five minutes at room temperature. The solution was sequentially extracted with equal volumes of TE ( $\mathrm{pH}$ 8.0) saturated phenol, phenol-chloroform-isoamyl alcohol and chloroform. DNA was precipitated by adding $1 / 10$ volume of $1 \mathrm{M} \mathrm{NaCl}$ and 2.2 volumes of $100 \%$ ethanol and

incubated for one hr. at $20^{\circ} \mathrm{C}$. The precipitated DNA, after centrifugation was rinsed three times with $70 \%$ ethanol, dried and resuspended in sterile distilled water. 


\subsection{Polymerase chain reaction}

The genomic DNA of individual bacterial samples was used for PCR amplification. The 16S rDNA gene fragments were amplified by PCR using the universal primers 27F (5'AGAGTTTGATCCTGGCTCAG-3') and 1492R (5'-GGTTACCTTGTTACGACTT-30) (Weisburg et al., 1991). The amplification was carried out in $25 \mu \mathrm{l}$ of reaction mixture containing DNA template, PCR buffer, dNTP $(10 \mathrm{mM}), \mathrm{MgCl} 2(25 \mathrm{mM})$, the primers $27 \mathrm{~F}(10 \mathrm{ppm})$ and 1492R (10 ppm) respectively, Taq polymerase (Sigma) (2U) and autoclaved Milli-Q water (Millipore). The amplification was carried out for 35 cycles of $94^{\circ} \mathrm{C}$, for $45 \mathrm{~s}, 60{ }^{\circ} \mathrm{C}$ for $45 \mathrm{~s}$ and $72{ }^{\circ} \mathrm{C}$ for $45 \mathrm{~s}, 72$ ${ }^{\circ} \mathrm{C}$ for 7 min with initial $05-m i n$ denaturation at $94^{\circ} \mathrm{C}$ using a PCR-Express thermal cycler (Hybaid). The DNA sequences of the PCR products were determined using a Taq Dye Deoxy terminator cycle sequence kit (Perkin-Elmer) using the protocol recommended by the supplier. Sequencing reaction products were analyzed with a model 373A automated DNA sequencer (Applied Biosystems). Databases (GenBank) were searched for sequences similarity analysis of the 16S rDNA sequence obtained. The sequences obtained were aligned with clustal $x$ and the tree was built by using MEGA 4.

\section{Results}

\subsection{Screening of carbohydrate degrading bacteria}

Screening of marine bacteria from Mondovi and Zuari estuaries resulted in the isolation of 536 bacterial isolates. The isolates were maintained and subcultured on Luria Agar or Zobell Marine Agar. Each bacterial isolate was then screened for the production of amylase, xylanase and cellulase by plate assay as described under the materials and methods (Fig. $2 a \quad \& 2 b$ ). It was seen that almost $66 \%$ of total bacteria isolated from this area had carbohydrate degrading abilities (Fig. 3a). In order to investigate the influence of salinity with abundance of carbohydrate degrading bacteria regression analysis was carried out (Fig. 3b) which showed that carbohydrate degrading bacteria are negatively correlated with salinity ( $p \leq 0.001)$ (Fig. 3b).

Fig. 2a. Detection of Amylase production as a clear white zone using Gram's-iodine in starch agar plates

Fig. 2b. Detection of xylanase/cellulase activity in xylan/CMC agar plates using Congo red

Fig. 3a. Percentage of carbohydrade degrading bacteria in Mandovi and Zuari estuary

Fig. 3b. Analysis of regression on carbohydrate degrading bacteria and salinity of different stations

The percentage of total carbohydrate degrading bacteria in Mandovi estuary was $60 \%$ as compared to Zuary estuary which was $77 \%$. Amongst the caarbohydrate degrading bacteria, amylase degrading bacteria were most dominant in Mandovi estuary (i.e. 83\%) than in Zuari estuary (75\%), followed by xylanase degraders (10\%) and (13\%) while cellulose degraders were $(6.7 \%)$ and (12\%) in Mandovi and Zuari estuaries respectively (Fig. 4a, 4b and Fig. 5a,5b).

Fig. 4a. Total carbohydrate degrading bacteria in Mandovi estuary 
Fig. 4b. Percentage of xylanase, cellulase and amylase degrading bacteria in Mandovi estuary

Fig. 5a. Total carbohydrate degrading bacteria in Zuary estuary

Fig. 5b. Percentage of xylanase, cellulase and amylase degrading bacteria in Zuary estuary

\subsection{Distribution of carbohydrate degrading bacteria}

The estuarine system of mandovi and Zuari estuaries are amongst one of the well studied systems and have been investigated from hydrological, tidal, biological viewpoints (Shetye et al., 2007). The results obtained in our study showed interesting trend of bacterial distribution at each station. In all the stations of Mandovi and Zuari, amylase degrading bacteria were the most dominant. It was seen that Donapaula station had only starch degraders while amylase producers were 10-20 times more than cellulose and hemicellulose degraders at Akkada, Usgao and Cortalim, while at Savordem and Sanguem they were just two times higher (Fig. 6). Observed differences in carbohydrate degrading bacteria at different stations is highly significant as evident from one-way ANOVA (Table 1).

Table 1. Result of one-way ANOVA comparing the carbohydrade degrading bacteria and different stations.

When only cellulose and hemicellulose degrading bacteria were studied it was seen that Donapaula station didn't show any cellulose or hemicellulose degrading bacteria. Chorao was mainly dominated by hemicellulase degraders. Akkada had both cellulose and hemicellulose degrading bacteria with almost equal proportion. Usgao and St. Cruze stations had bacteria with equal proportion of hemicellulose degraders and bacteria which can degarade both cellulose and hemicellulose together. Chikalim and Savordem stations showed all three types of bacteria, while Cortalim had only hemicellulase degrading bacteria. Loutlim was the first station which was dominated by cellulose degrading bacteria, while Sanguem was dominated by bacteria having multiple substrate degrading capabilities (Fig. 7)

Fig. 6. Distribution of Cellulose and Hemicellulose and Amylose degrading bacteria in Mandovi and Zuary estuary

Fig. 7. Distribution of Cellulose and Hemicellulose degrading bacteria in Mandovi and Zuary estuary

\subsection{Phylogenetic diversity}

Molecular phylogeny of Xylanase and cellulase producing isolates was carried out by employing 16s rDNA sequencing. Comparison of these sequences with those in gene bank database (accession numbers: HM486447-HM486493) indicated that the majority of cellulose and hemicellulose degrading isolates from Mandovi and Zuary estuary belong to Bacillus genera 
followed by Vibrio, Marinobacter, Exiquinobacterium, Alteromonas, Enterobacter and Aeromonas (Table 2).

Table 2. Relative abundance (\%) of cellulose and hemicellulose degrading marine bacteria.

Most abundant bacterial genus to degrade hemicellulose and cellulose were Bacillus and Vibrio respectively. It was seen that $46 \%$ of Bacillus isolates had ability to degrade both the substrate while only $14 \%$ of Vibrio showed had bifunctionality. It was seen that $39 \%$ Bacillus degraded hemicellulose but only $15 \%$ Bacillus sp could degrade cellulose exclusively (Fig. 8).

Fig. 8. Degradation pattern of Bacillus sp (a). and Vibrio sp. (b) with respect to hemicellulose and cellulose

Fig. 9 shows a phylogenetic tree based on 16S r DNA sequences of 47 culturable isolates degrading cellulose and hemicellulose found in and Zuari estuarine region. The Bacillus and Vibrio isolates although very similar in rDNA sequences show variations in enzyme production and appear to colonise the diverse ecological niches.

Fig. 9. Phylogenetic relationship based on $16 \mathrm{~S}$ rDNA sequences of representative isolate and related species degrading carbohydrate found in Mandovi and Zuary estuary-Goa. This tree was generated using the program ClustalX. It can be clearly seen that all the Bacillus species show clustering and several Bacillus pumilis isolates clearly differ in the rDNA sequence compositions. Although similar trend is seen in Vibrio isolates there is a lot of diversity amongst the various bacillus isolates in terms of their abilities to produce enzymes and rDNA sequence homologies.

\section{Discussion}

Marine microorganisms possess a wide range of enzymes which metabolise carbohydrate and are different from those of terrestrial microbes. Detection of the enzymes that hydrolyze natural compounds in the ocean and their further investigation is scientifically and practically significant, making it possible to elucidate the mechanisms of the transformation of organic substances in marine ecosystems and to fulfil the requirements of modern biotechnology (Beleneva et al., 2010). Thus, this research is oriented to the isolation of carbohydrate degrading bacterial enzymes in marine environment with special emphasis on celluloses and hemicelluloses.

Most of the samples collected from Mandovi and Zuary estuary had high densities of culturable bacteria $\left(10^{3}\right.$ to $\left.10^{6}\right)$. The number of carbohydrate degraders isolated amongst them was quite large $(66 \%)$. The isolation of large number of carbohydrate degraders belonging to different groups highlights the important role of these micro organisms in carbohydrate turnover in Mandovi and Zuary estuary. It has been reported by Beleneva et al. (2010) that the strains isolated from temperate climatic zone possess higher enzymatic activity than those isolated from the tropical zone. Extracellular enzyme activity of these organisms is a very important feature in the ecology of 
water because it is responsible for that part of detritus which is introduced into the food chain via bacterial heterotrophic activity.

If we compare Mandovi and Zuary estuary, the carbohydrate degraders were more in Zuary compared to Mandovi. The Amylase producers dominated at both the estuaries. Derekova et al. (2008) also reported that amylose was the most preferable substrate, and about half of the isolates from Bulgarian hot springs degraded it. The observed high frequency of amylolytic activity between the isolated strains could be explained by ubiquitous occurrence of starch in nature and its comparatively easy degradation.

There has been considerable interest in microbial and enzymatic conversion of cellulosic and hemicellulosic substrates, such as waste plant cell wall material. Its successful utilization as renewable raw material depends on the development of economically feasible technologies for the hydrolysis into low molecular weight products and for the conversion of these hydrolysis products into commercial products such as liquid fuel, food materials, and chemicals (Risna and Suhirman, 2002). In this context, cellulose and hemicellulose degrading bacteria from this region were studied more closely. It was seen that Donapaula station didn't show any cellulose and hemicellulose degrading bacteria, while some stations such as Cortalim and Loutlim were completely dominated by xylanase and cellulase degraders respectively. Most interestingly some stations such as Sanguem and Savordem showed the dominance of bifunctional bacteria which could degrade both hemicellulose and cellulose. Sanguem and Savordem is a reverine end of Mandovi estuary with fresh water, while Donapaula is a mouth of estuary with salinity of 35ppt. It is been reported that the growth rate of lignocellulose-degrading populations $(50 \%)$ is inhibited by $\mathrm{NaCl}$ (Liu and Boone,1991). Also according to park et al. 2006 the high salinity seems to significantly reduce ectoenzyme activities. Thus it is possible that the type of bacterial population found at particular station can also be influenced by salinity changes. It has also been reported that in most of the aquatic environments there is a significant relationship between extracellular enzyme activities, their corresponding substrates (polymers) and their hydrolysis products (monmers) (Munster et al., 1992). Thus the presence of cellulolytic and hemicellulolytic bacteria in particular region while absence of these bacteria in other region indicates the presence of wide-ranging organic matter in each region. Previous research has also put forth a widely accepted concept that hydrolytic enzymes are induced by the presence of polymeric substrates (Chrost, 1991; Vetter and Deming, 1999).

It was observed that the genus Bacillus and Vibrio were the dominant hemicellulase and cellulase producers in both the estuaries. According to Ruger, (1989) the genus Bacillus is comprised of a phylogenetically and phenotypically diverse species, which are ubiquitous in terrestrial and fresh water habitat and are also widely distributed in sea water. While the family Vibrionaceae is one of the most important bacterial groups in marine environments. Members of this family often predominate in the bacterial flora of seawater, plankton, and fish. In a survey carried out 
in the West Pacific Ocean, Vibrios accounted for nearly $80 \%$ of the bacterial population in surface seawater (Shimidu et al., 1980). Phylogenetic diversity of the culturable bacterial species from Bulgarian hot springs has been described along with their carbohydrate utilising abilities (Derekova et al., 2008)

It was seen that organisms belonging to the bacterial genus Bacillus could efficiently degrade hemicelluloses and also showed effective bifunctionality. While only few Bacillus isolates could degrade cellulose exclusively. Bacillus species are known to produce a number of extracellular polysaccharide hydrolysing enzymes (Priest, 1977) and several Bacillus spp. are known to produce xylanases (Nakamura et al., 1993, Morales et al., 1993, Ratanakhanokchai et al., 1999, Yin et al., 2010). It has also been reported that bacilli lack the complete cellulase system, the main activity being that of carboxymethylcellulase (endoglucanase) which does not hydrolyse crystalline cellulose (Robson and Chambliss, 1987, Dhillon et al., 1985, Au and Chan, 1987, Okoshi et al., 1990, Ozaki and ito, 1991, Aa et al., 1994 ). This may be the reason behind reduced efficiency of Bacillus in degrading cellulose. On the other hand, Vibrio was seen to degrade cellulose very efficiently. Although a few Vibrio isolates demonstrated bifuntionality, very few had ability to degrade hemicellulose. While all cellulases cleave a single type of bond in a chemically simplistic substrate, the extensive intermolecular bonding pattern of cellulose generates a fascinating crystalline substrate that is particularly resistant to microbial degradation. Multiple enzyme systems are thus required to efficiently degrade cellulose. Such systems comprise either a collection of free cellulases and/or multicomponent complexes thereof, called cellulosomes. It is likely that marine Vibrios may posess cellulosomes which help them to degrade cellulose while Bacillus does not. It is reported by Demain, (2006) that along with other bacteria such as some of Clostrdium sp. and Ruminococcus sp., Vibrio sp. also posses cellulosomes.

Different strains of Bacillus subtilis and Bacillus pumilis were found all over the Mandovi and Zuary estuary involved in celloulose and hemisellulose degradation. Miranda et al., (2008) have described the identification of 23 marine Bacillus isolates by rDNA sequencing. In our molecular phylogenetic analysis it can be seen that amongst the Bacillus species described, these isolates show variation in rDNA sequence and also differ in their abilities to produce glucanases. Thus Bacillus seems to adapt to changing salinity and differential availability of complex carbohydrates by colonising different specialised niches

It is estimated that the $50 \%$ of the primary production is cycled as dissolved organic carbon (DOC) through the microbial loop to higher trophic levels (Azam, 1998). Carbohydrates are one of the major forms of organic substrates in the aquatic environment, contributing up to $80 \%$ of the dissolved and $5-25 \%$ of the particulate organic carbon. Thus, Detection of the enzymes that hydrolyze carbohydrates in the ocean and their further investigation is scientifically and practically significant, making it possible to elucidate the mechanisms of the transformation of organic substances in marine ecosystems and to fulfil the requirements of modern biotechnology. 


\section{Acknowledgements}

The authors are grateful to Dr. Satish R. Shetye, Director, National Institute of Oceanography (CSIR), Goa (India) for facilities and encouragement.

\section{References}

$>$ Aa, K., Flengsrud, R., Lindahl, V., Tronsmo, A., 1994. Characterisation of production and enzyme properties of an endo- $\beta-1,4$-glucanase from Bacillus subtilis CK-2 isolated from compost soil. Antonie van Leeuwenhoek 66, 319-326.

Au, K.S., Chan, K.Y., 1987. Purification and properties of endo-1,4- $\beta$-glucanase from Bacillus subtilis. Journal of General Microbiology 133, 2155-2162.

Ausubel, F.M., Brent, R., Kingston, R.E., Moore, D.D., Siedman, J.G., Smith, J.A., Struhl, K., 1995. Short Protocols in Molecular Biology. Wiley pp. 2.11-2.12.

$>$ Azam, F., Worden, A.Z., 2004. Microbes, molecules, and marine ecosystems. Science 303,1622-1624.

Benner, R., Pakulski, J.D., McCarty, M., Hedges, J.I., Hatcher, P.G., 1992. Bulk chemical characteristics of dissolved organic matter in the ocean. Science 255,1561-1564.

Beleneva, I.A., Agarkova, V.V., Kukhlevskiya, A.D., Zviagintseva T.N., 2010. Distribution of the enzymes of carbohydrate metabolism among marine microorganisms in the sea of Japan and the South Chinese sea Microbiology 79, 791-798.

$>$ Biersmith, A., Benner, R., 1998. Carbohydrates in phytoplankton and freshly produced dissolved organic matter. Marine Chemistry 63,131-144.

$>$ Chrost R. J., 1991. Environmental control of the synthesis and activity of aquatic microbial ectoenzymes. In: Microbial enzymes in aquatic environments. Springer, 29-59.

$>$ Decho, A.W., 1990. Microbial exopolymer secretions in the ocean environments their role(s) in food webs and marine processes. Oceanography and Marine Biology An Annual Review 28, 73-153.

$>$ Demain, A.L., 2006. The crucial importance of bioethanol and the contribution of anaerobic bacteria and there cellulosomes. In: Cellulosome. Eds. V. Uversky and I A Kataeva, 1-9.

$>$ Derekova, A., Mandeva, R., Kambourova, M., 2008. Phylogenetic diversity of thermophilic carbohydrate degrading Bacilli from Bulgarian hot springs. World Journal of Microbiology Biotechnology 24,1697-1702.

$>$ Dhillon, N., Chibber, S., Saxena, M., Pajni, S., Vadehra, D.V., 1985. A constitutive endoglucanase (CMCase) from Bacillus licheniformis-1. Biotechnology Letters, 695-697.

$>$ Gilbert, H.J., Hazlewood, G.P., 1991. Genetic modification of fiber digestion. Proceedings of the Nutrition Society 50,173-186.

Lennon, J.T., 2007. Diversity and Metabolism of Marine Bacteria Cultivated on Dissolved DNA. Applied and Environmental Microbiology 73, 2799-2805.

Liu, Y., Boone, D.R., 1991. Effects of salinity on methanogenic decomposition. Bioresource Technology 35, 271-274.

$>$ Maki, M., Leung, K.T., Qin, W., 2009. The prospects of cellulase-producing bacteria for the bioconversion of lignocellulosic biomass. International Journal of Biological Sciences 5, 500-516.

> Miranda, C.A.C., O.B., Martins., Clementino, M.M., 2008 Species-level identification of Bacillus strains isolates from marine sediments by conventional biochemical,16S rRNA 
gene sequencing and inter-tRNA gene sequence lengths analysis. Antonie van Leeuwenhoek 93,297-304.

Morales, P., Madarro, A., Pérez-González, J.A., Sendra, J.M., Piñaga, F., Flors, A., 1993. Purification and Characterization of Alkaline Xylanases from Bacillus polymyxa. Applied and Environmental Microbiology 59(5), 1376-1382.

Nakamura, S., Wakabayashi, K., Nakai, R., Aono, R., Horikoshi, K., 1993. Production of alkaline xylanase by a newly isolated alkaliphilic Bacillus sp strain 41M-I. World Journal of Microbiology and Biotechnology 9, 221-224.

Ninawe, S., Kuhad, R.C., 2006 Bleaching of wheat straw-rich soda pulp with xylanase from a thermoalkalophilic Streptomyces cyaneus SN32. Bioresource Technology 97, 2291-2295.

Okoshi, H., Katsuka, O., Shikata, S., Oshino, K., Kawai, S., Ito, S., 1990. Purification and characterisation of multiple carboxymethylcellulases from Bacillus sp. KSM-522. Agricultural and Biological Chemistry 54, 83-89.

$>$ Ozaki, K., Ito, S., 1991. Purification and properties of an acid endo- $\beta-1,4-$ glucanase from Bacillus sp KSM-330. Journal of General Microbiology 137, 41-48.

$>$ Pointing, S.B., Hyde, K.D., 2000. Lignocellulose-degrading Marine Fungi. Biofouling 15, 221229.

> Priest, F.G., 1977. Extracellular enzyme synthesis in the genus Bacillus. Bacteriology Review 41,711-753.

$>$ Ratanakhanokchai, K., Kyu, K.L., Tanticharoen, M., 1999. Purification and Properties of a Xylan-Binding Endoxylanase from Alkaliphilic Bacillus sp. Strain K-1. Applied and Environmental Microbiology 65, 694-697.

$>$ Risna, R.A., Suhirman, 2002. Ligninolytic enzyme production of Polyporaceae from Lombok, Indonesia. Fungal Diversity 9,123-134.

$>$ Robson, L.M., Chambliss, G.H., 1984. Characterization of the cellulolytic activity of a Bacillus isolate. Applied and Environmental Microbiology 47, 1039-1046.

$>$ Rosado, W., Govind, N.S., 2003. Identification of carbohydrate degrading bacteria in subtropical regions. Revista de Biología Tropical 51, 205-210.

$>$ Ruger, H.J., 1989. Benthic studies of the northwest African upwelling region psychrophilic bacterial communities from areas with different upwelling intensities. Marine Ecological Progress Series 57, 45-52.

$>$ Shetye, S.R., Kumar, M.D., Shankar, D., 2007. The Mandovi and Zuari Estuaries, National Institute of Oceanography, Goa .145 pp.

> Simidu, U.N., Taga, R.R., Cohvell, Schwartz J. R., 1980. Heterotrophic bacterial flora of the seawater from the Nansei Shoto (Ryukyu Retto) area. Bulletine. Japanese. Society of Science and Fisheries. 46505-510.

$>$ Vetter, Y.A., Deming, J.W., 1999. Growth Rates of Marine Bacterial Isolates on Particulate Organic Substrates Solubilized by Freely Released Extracellular Enzymes. Microbial Ecology 37, 86-94.

$>$ Weisburg, W.G., Barns, S.M., Pelletier, D.A., Lane, D.J., 1991. 16S ribosomal DNA amplification for phylogenetic study. Journal of Bacteriology 697-703.

$>$ Yin, L.J., Lin, H.H., Xiao, Z.R., 2010. Purification and characterization of a cellulase from Bacillus subtilis. Journal of Marine Science Technology 18, 466-471. 


\section{Figure captions}

Fig.1. Mandovi and Zuari estuary

Fig. 2a. Detection of Amylase production as a clear white zone using Gram's-iodine in starch agar plates

Fig. 2b. Detection of xylanase/cellulase activity in xylan/CMC agar plates using Congo red

Fig. 3. Percentage of carbohydrade degrading bacteria in Mandovi and Zuari estuary

Fig. 4a. Total carbohydrate degrading bacteria in Mandovi estuary

Fig. 4b. Percentage of xylanase, cellulase and amylase degrading bacteria in Mandovi estuary

Fig. 5a. Total carbohydrate degrading bacteria in Zuary estuary

Fig. 5b. Percentage of xylanase, cellulase and amylase degrading bacteria in Zuary estuary

Fig. 6. Distribution of Cellulose and Hemicellulose and Amylose degrading bacteria in Mandovi And Zuary estuary

Fig. 7. Distribution of Cellulose and Hemicellulose degrading bacteria in Mandovi And Zuary estuary Fig. 8. Degradation pattern of Bacillus $\mathrm{sp}$ (a). and Vibrio sp. (b) with respect to hemicellulose and cellulose

Fig. 9. Phylogenetic relationship based on $16 \mathrm{~S}$ rDNA sequences of representative isolate and related species degrading carbohydrate found in Mandovi and Zuary estuary-Goa. This tree was generated using the program Clustal $X$ 
Table 1

Result of one-way ANOVA comparing the carbohydrade degrading bacteria and different stations.

\begin{tabular}{llllll}
\hline Source of Variation & df & SS & MS & F & P-value \\
& & & & & \\
\hline \% Carbohydrate degrading & & & & & \\
bacteria & 9 & 2186.8 & 242.9778 & 121.4889 & $5.09 E-09$ \\
Between Groups & 10 & 20 & 2 & & \\
Within groups & 19 & 2206.8 & & & \\
Total & & & & & \\
\hline
\end{tabular}

Table 2

Relative abundance (\%) of cellulose and hemicellulose degrading marine bacteria.

\begin{tabular}{ll}
\hline Bacterial Genera & (\%) \\
\hline Bacillus & 70 \\
Vibrio sp & 17 \\
Marinobacter & 4 \\
Exiquobacterium auranticum & 2 \\
Alteromonas & 2 \\
Enterobacter oryzae/ & 2 \\
Aeromonas & 2 \\
\hline
\end{tabular}


Fig.1. Mandovi and Zuari estuary.

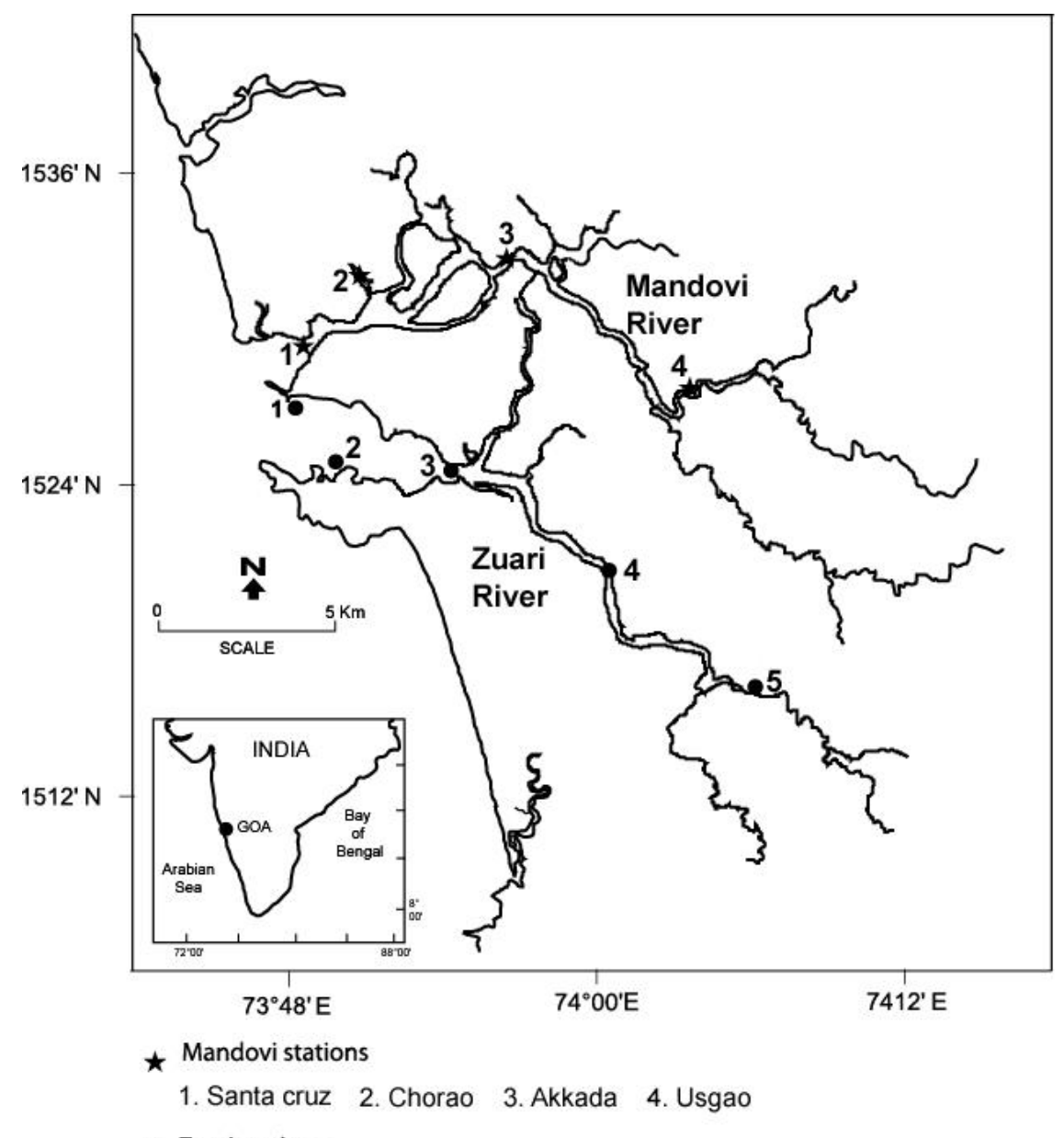

- Zuari stations

1. Dona paula 2. Chicalim 3. Cortalim 4. Sanguem

5. Savordem 

plates.

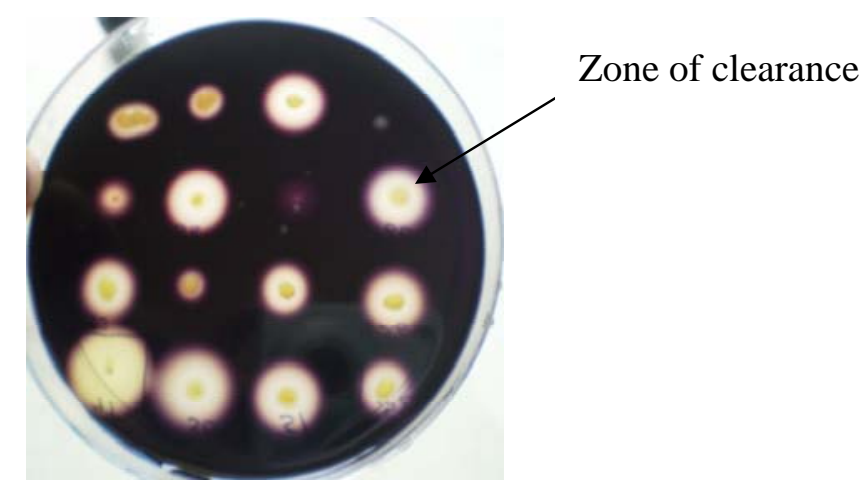

Fig. 2b. Detection of xylanase/cellulase activity in xylan/CMC agar plates using Congo red.

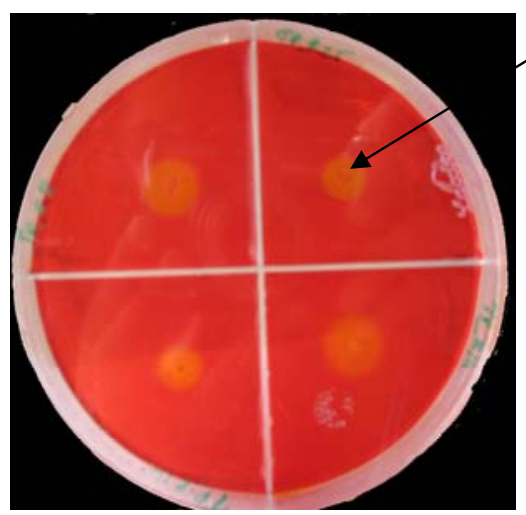

Zone of clearance 
Fig. 3. Percentage of carbohydrade degrading bacteria in Mandovi and Zuari estuary.

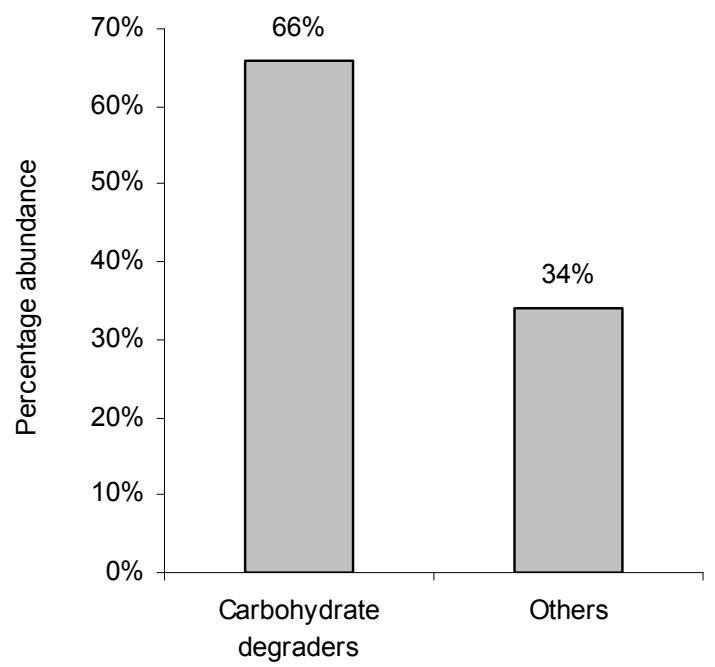

Fig. 3b. Analysis of Regression on carbohydrate degrading bacteria and salinity of different stations

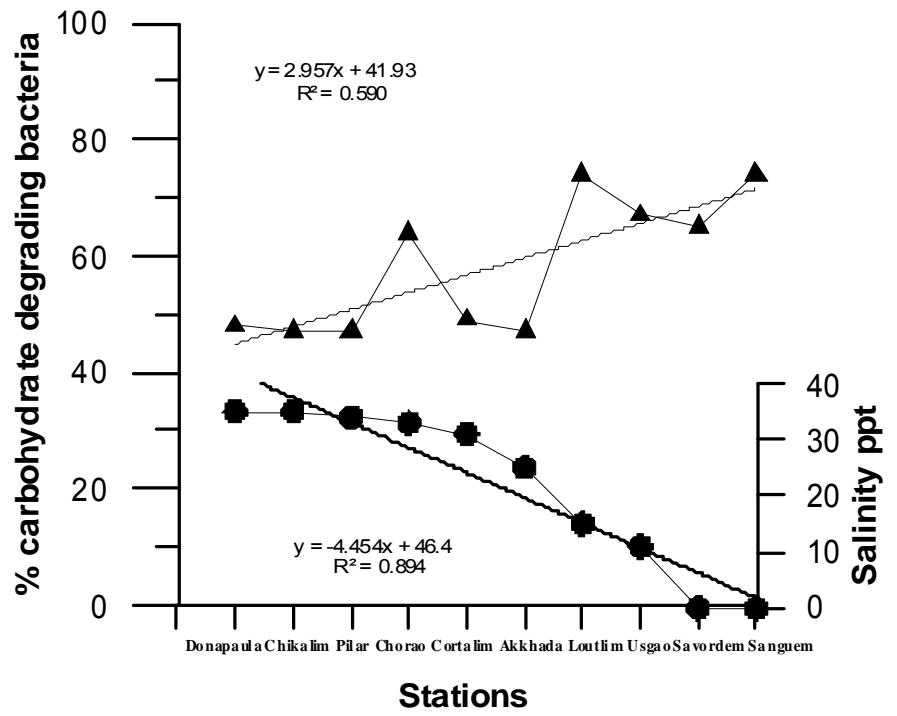


Fig. 4a. Total carbohydrate degrading bacteria in Mandovi estuary

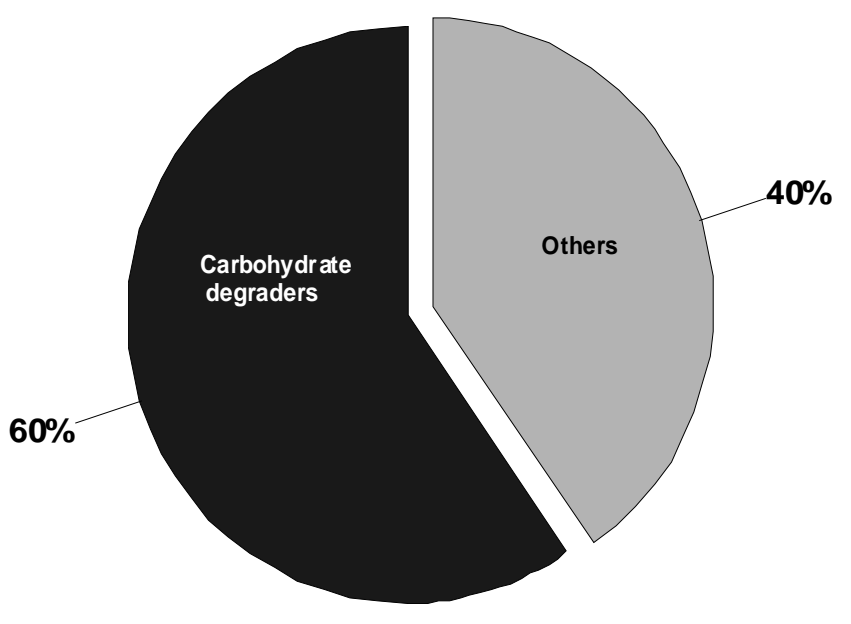

Fig. 4b. Percentage of xylanase, cellulase and amylase degrading bacteria in Mandovi estuary

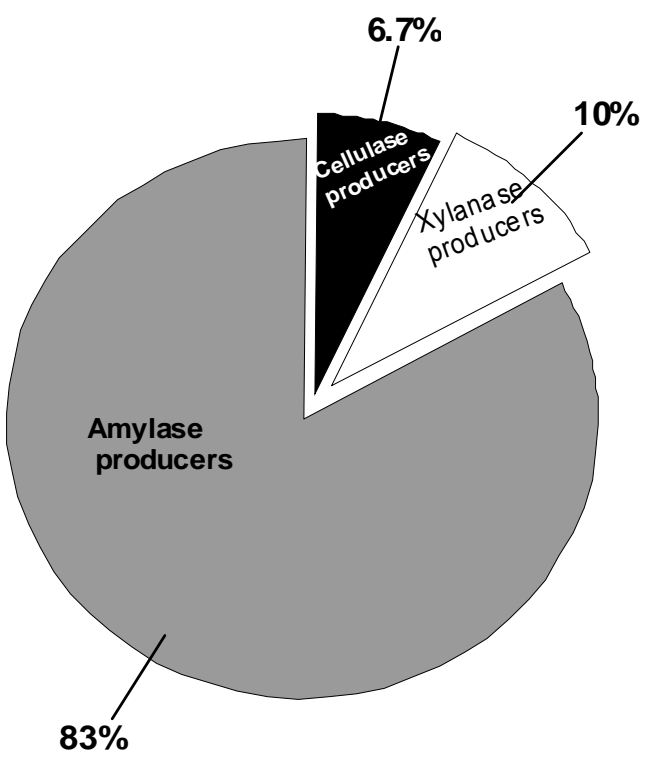


Fig. 5a. Total carbohydrate degrading bacteria in Zuary estuary.

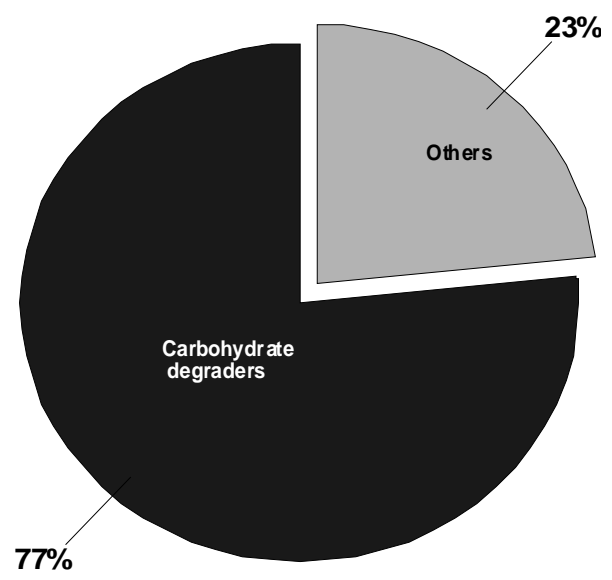

Fig. 5b. Percentage of xylanase, cellulase and amylase degrading bacteria in Zuary estuary

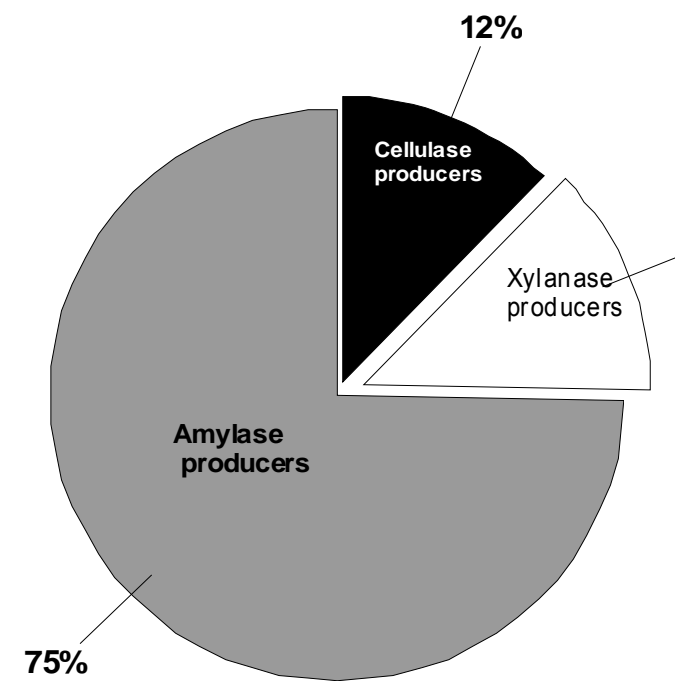

$13 \%$ 
Fig. 6. Distribution of Cellulose and Hemicellulose and Amylose degrading bacteria in Mandovi And Zuary estuary.

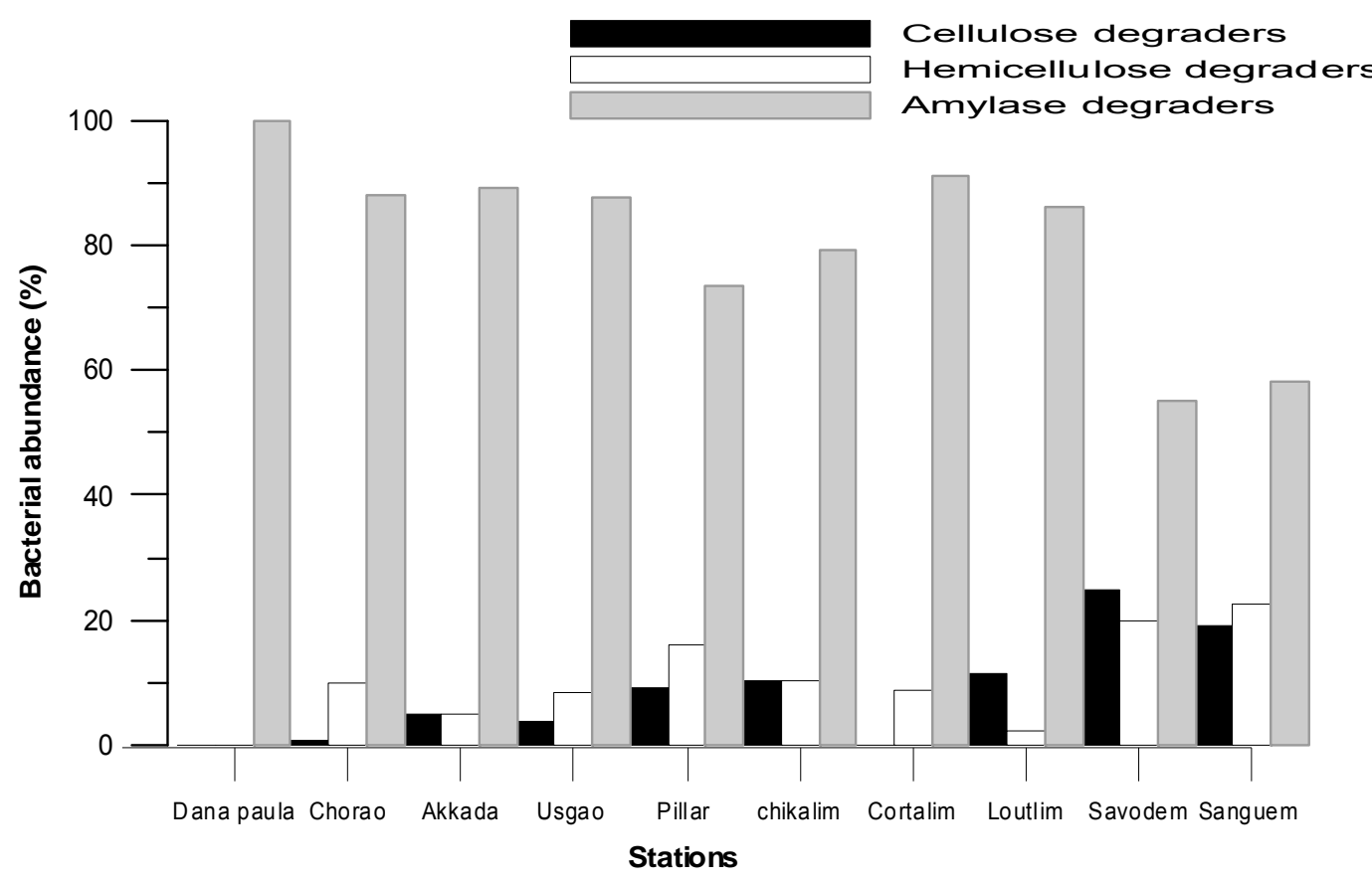


Fig. 7. Distribution of Cellulose and Hemicellulose degrading bacteria in Mandovi And Zuary estuary.

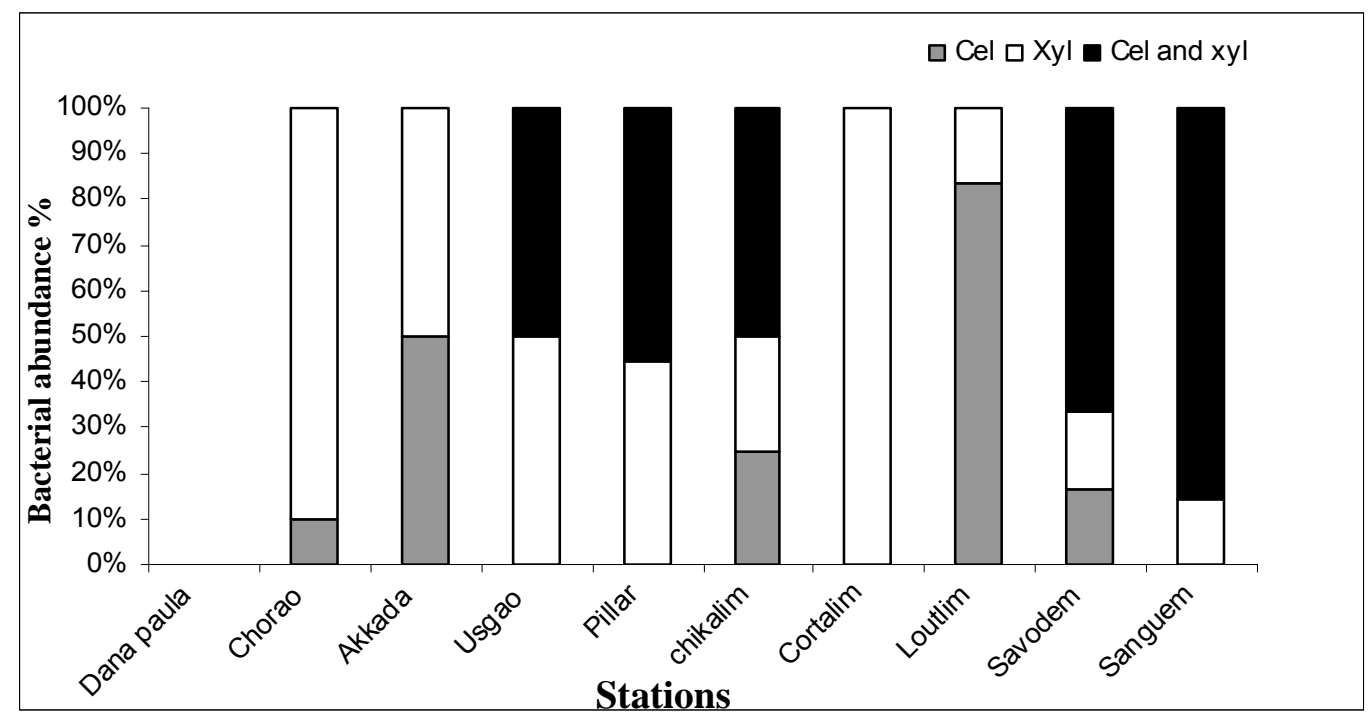


Fig. 8. Degradation pattern of Bacillus sp (a). and Vibrio sp. (b) with respect to hemicellulose and cellulose.

a

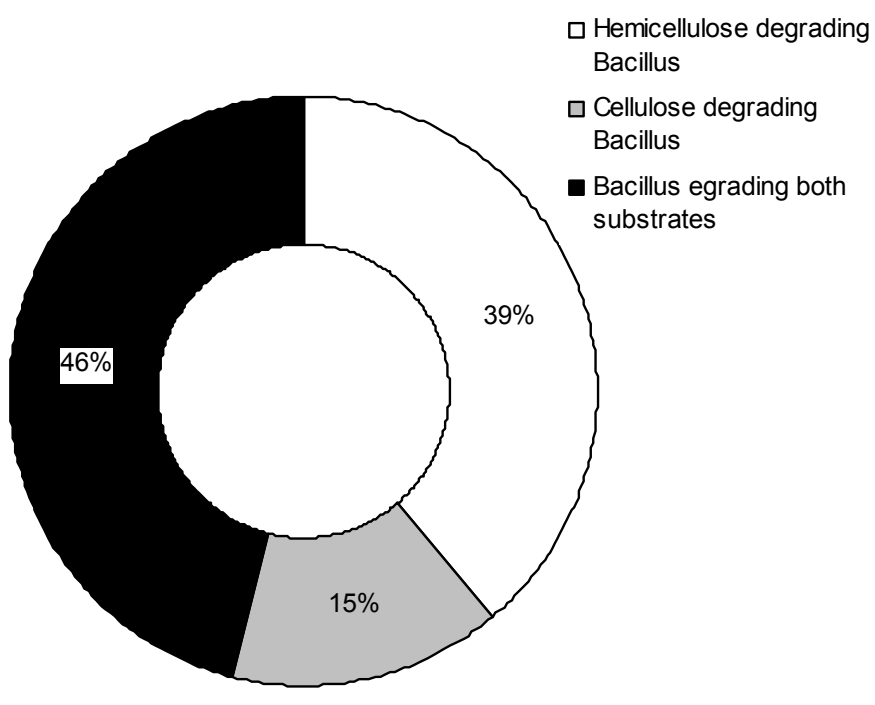

b

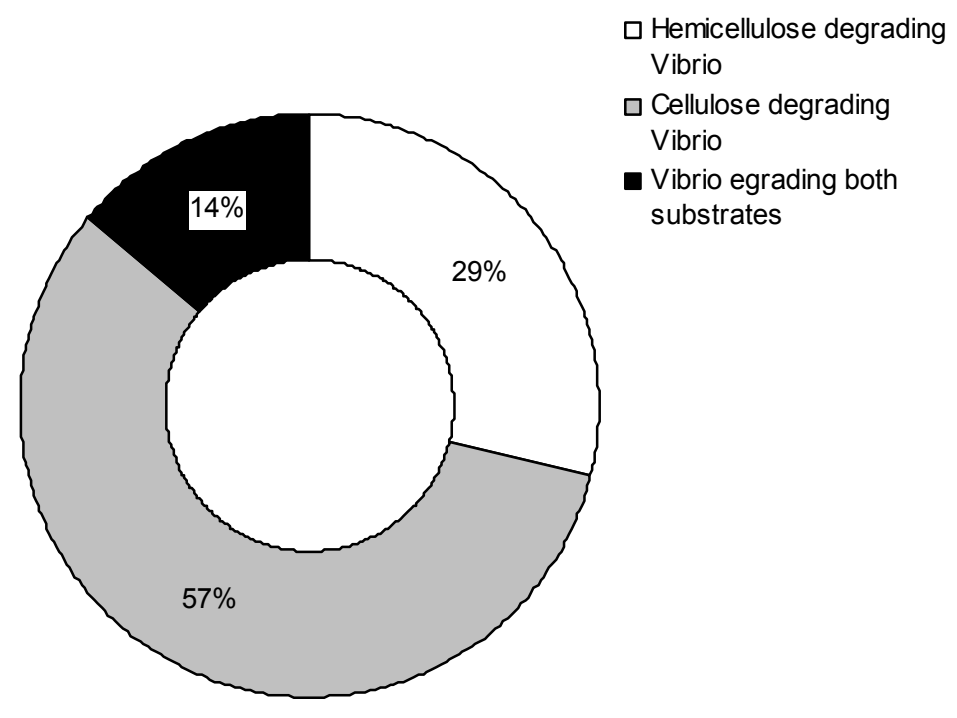


Fig. 9. Phylogenetic relationship based on $16 \mathrm{~S}$ rDNA sequences of representative isolate and related species degrading carbohydrate found in Mandovi and Zuary estuary-Goa. This tree was generated by using the program ClustalX

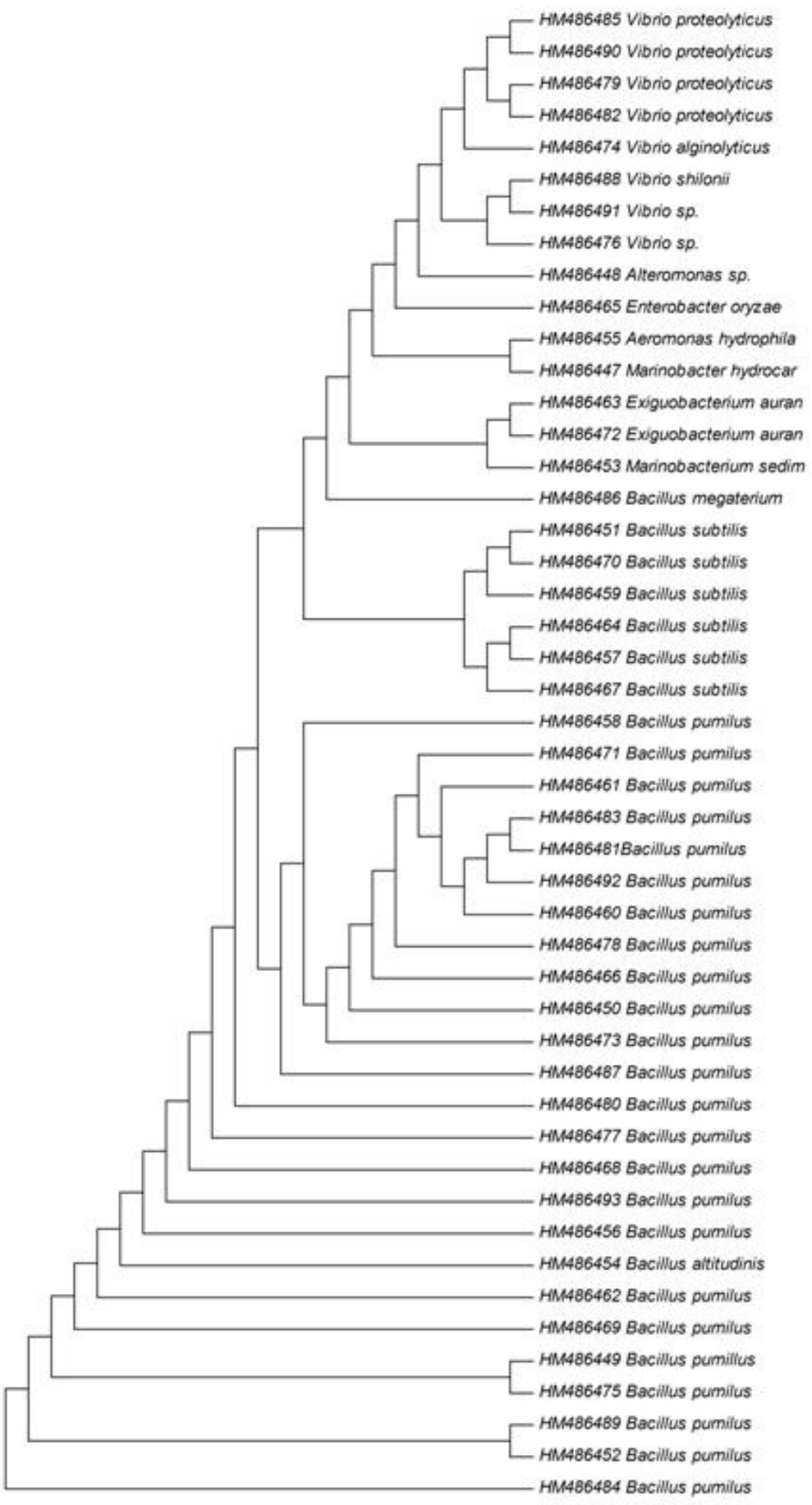

